\title{
Biochemical Response to 1,1-Dimethylhydrazine (UDMH)
}

\author{
Herbert H. Cornish and Mary L. Barth \\ Department of Industrial Health, School of Public Health, and Instituie of Industrial Health, \\ University of Michigan, Ann Arbor, Michigan
}

Received October 14, 1963

Owing to their present use as rocket fuels and their pharmacologic activity as central nervous system stimulants, substituted hydrazines and hydrazine derivatives have come into increasing use in recent years. The parent compound hydrazine and the methyl-substituted hydrazines are of potential hazard because of their toxicity, volatility, and explosive nature. Exposure to hydrazine vapor brings about central nervous system (CNS) effects resulting in clonic-tonic convulsions and death if the exposure is severe; in addition, hydrazine at lower levels of exposure will severely damage the liver, resulting in necrosis and fatty infiltration (Comstock et al., 1954). Inhalation of 1,1-dimethylhydrazine (unsymmetrical dimethylhydrazine, UDMH), while producing similar CNS effects, is apparently lacking the severe hepatotoxic effects of hydrazine (Rinehart et al., 1960).

The differences in hepatotoxic action and the exact mechanisms by which these compounds exert their CNS effects are not clear, although several recent reports have demonstrated that UDMH inhibits glutamic acid decarboxylase and $\gamma$-aminobutyric$\alpha$-ketoglutaric transaminase activities in brain tissue. This inhibition can be reversed and CNS symptoms alleviated by pyridoxine hydrochloride (Medina et al., 1962; Reeves, 1961).

The present study was undertaken with two objectives in mind: to study the cytotoxic effect of UDMH on tissues and to evaluate several techniques that might be of value as sensitive indexes of tissue damage due to UDMH exposure. Serum glutamicoxalacetic transaminase (GOT) was determined since it has been shown to be a relatively sensitive index of liver damage. Urinary amino acid excretion was measured since it may reflect liver or kidney damage or altered protein and amino acid metabolism. Brain and liver sulfhydryl levels were also studied, as they may be affected by the chemical reactivity of UDMH or by its effect on the oxidation-reduction state of the tissue. Histopathologic examination of the various tissues was also included in this study.

\section{MATERIALS AND METHODS}

UDMH used in these studies was Eastman Kodak practical grade. For intraperitoneal injection, UDMH was dissolved in $27 \mathrm{mM}$ bicarbonate in $0.9 \%$ saline solution (Reeves, 1961).

All animals were male rats of the Sprague-Dawley strain (Rawley Farms), approximately $225-275 \mathrm{~g}$ in weight. The animals utilized for enzyme studies and sulfhydryl levels were maintained on an ad libitum diet of Rockland Chow. The rats used for amino acid excretion studies were fed a normal protein test diet from Nutritional 
Biochemical Corporation. These rats were housed in individual metabolism cages designed for the collection of urine uncontaminated by feces. Twenty-four-hour urine samples were collected, diluted to $20 \mathrm{ml}$ with distilled water, and filtered. Three drops of toluene were added to each filtrate and all samples were kept in a refrigerator for subsequent paper chromatographic studies. Urinary amino acids were determined in triplicate according to the method of Khachadurian et al. (1960). Each rat served as its own control, and 24-hour urine samples were collected for a 5-day period before and after UDMH injection. The urines were analyzed for their creatinine content by the Jaffe reaction. The results are also expressed as the ratio of $\alpha$-amino acid nitrogen to creatinine nitrogen.

Ascending paper chromatography was carried out on $18 \times 22$-cm sheets of Whatman no. 1 paper. The solvent systems used were: methanol, $n$-butanol, benzene, water (2:1:1:1) and phenol saturated with buffer (6.3\% sodium citrate, $3.7 \%$ sodium dihydrogen phosphate). For the detection of amino acids, the dried chromatograms were sprayed with $0.2 \%$ ninhydrin in $95 \%$ ethanol. Serum glutamic-oxalacetic transaminase (GOT) activity was determined by the method of Steinberg et al. (1956). These enzyme studies were done on serum samples obtained from rats 18 hours and 5-7 days after the injection of UDMH. The 18-hour time interval was chosen on the basis of previous studies which indicate that in acute liver intoxication from $\mathrm{CCl}_{4}$ poisoning, the serum enzyme levels reach a maximum 18-24 hours after administration of the toxic compound (Cornish and Block, 1960). The 5-7 day studies were included to check for any latent toxicity that might develop.

Animals to be used for sulfhydryl determinations were stunned by a blow on the head and killed by decapitation. Tissues to be analyzed were removed at once, weighed, and homogenized immediately with 9 parts of cold $2.5 \%$ sulfosalicylic acid in an all-glass tissue grinder. Liver samples were cut into small pieces, disintegrated with 4-6 strokes, and finally given 20 strokes to complete the process. Brain lissue was given 20 strokes to disintegrate the whole organ. The homogenates were centrifuged for 15 minutes at $8000 \mathrm{rpm}$ in a cold room. The supernatant fluid was analyzed according to the amperometric titration method of Benesch and Benesch (1950). The titrations were done in $4.8 \mathrm{M}$ methanol using a supporting electrolyte $1.5 \mathrm{M}$ in $\mathrm{NH}_{4} \mathrm{NO}_{3}$ and $7.5 \mathrm{M}$ in $\mathrm{NH}_{4} \mathrm{OH}$. One milliliter of standard glutathione $(0.001 \mathrm{~N})$, $2 \mathrm{ml}$ liver homogenate, or $3 \mathrm{ml}$ brain homogenate was added to a mixture of $1 \mathrm{ml}$ supporting electrolyte and enough aqueous methanol to give a total of $31 \mathrm{ml}$. Nitrogen was bubbled through this solution for 10 minutes, the rotating platinum electrode acting as a stirrer. The titration was carried out with $1 \times 10^{-3}$ normal $\mathrm{AgNO}_{3}$, using a syringe microburette. The end point was determined from a plot of current versus milliliters of $\mathrm{AgNO}_{3}$ used in the titration.

\section{RESULTS}

\section{Acute Intraperitoneal Toxicity}

In order to find an appropriate working level where relatively large amounts of UDMH could be routincly injected, an acute toxicity study was carried out with the following results (Table 1). Eighty milligrams of UDMH per kilogram was the maximum intraperitoneal dose which allowed all animals to survive. At $100 \mathrm{mg} / \mathrm{kg}, 2$ of 4 rats died and at $120 \mathrm{mg} / \mathrm{kg}$, all rats died. The approximate intraperitoneal $L_{50}$ 
value, calculated on the basis of these preliminary studies, is $100 \mathrm{mg} / \mathrm{kg}$. Mild to severe convulsions were evident in the $80-120 \mathrm{mg} / \mathrm{kg}$ dose range at the times noted in Table 1.

TABLE 1

Mortality in Rats Following THE InTRaperitoneal InJection of UDMH

\begin{tabular}{|c|c|c|c|c|}
\hline \multirow{3}{*}{$\begin{array}{l}\text { Time after } \\
\text { injection } \\
\text { (hours) }\end{array}$} & \multicolumn{4}{|c|}{ Dosage } \\
\hline & $60 \mathrm{mg} / \mathrm{kg}$ & $80 \mathrm{mg} / \mathrm{kg}$ & $100 \mathrm{mg} / \mathrm{kg}$ & $120 \mathrm{mg} / \mathrm{kg}$ \\
\hline & $\mathrm{NS}^{a} 0 / 4$ & NS $\quad 0 / 4$ & $\mathrm{SC}^{b} \quad 0 / 4$ & $\mathrm{SC} \quad 0 / 4$ \\
\hline 2 & NS $\quad 0 / 4$ & $\mathrm{MC}^{c} \quad 0 / 4$ & $\mathrm{SC} \quad 0 / 4$ & $\mathrm{SC} \quad 0 / 4$ \\
\hline 4 & NS $0 / 4$ & $\mathrm{MC} \quad 0 / 4$ & $\mathrm{SC} \quad 2 / 4$ & SC $1 / 4$ \\
\hline 6 & NS $\quad 0 / 4$ & $\mathrm{MC} \quad 0 / 4$ & $\mathrm{SC} \quad 2 / 4$ & $\mathrm{SC} \quad 4 / 4$ \\
\hline 8 & NS $0 / 4$ & MC $\quad 0 / 4$ & $\mathrm{SC} \quad 2 / 4$ & - \\
\hline Total deaths & $0 / 4$ & $0 / 4$ & $2 / 4$ & $4 / 4$ \\
\hline
\end{tabular}

${ }^{a} \mathrm{NS}$, no symptoms.

${ }^{b} \mathrm{SC}$, severe convulsions.

o MC, mild convulsions.

The growth curves of rats given a single intraperitoneal injection of 40,60 , or 80 $\mathrm{mg} / \mathrm{kg}$ of UDMH on day 5 are shown in Fig. 1. Only at the $80 \mathrm{mg} / \mathrm{kg}$ dose level was an actual weight loss noticeable. This occurred only on the day following the injection. Food consumption was also decreased by approximately $30 \%$ during the 24-hour

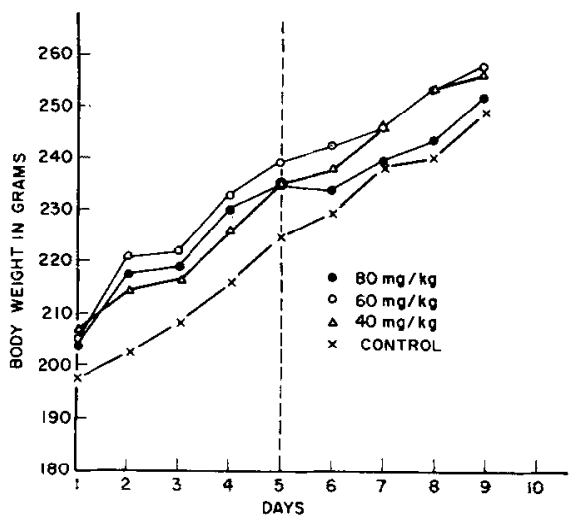

FIG. 1. Growth curves of rats receiving a single intraperitoneal dose of UDMH.

period following the injection of $80 \mathrm{mg} / \mathrm{kg}$ of UDMH. Both food consumption and weight gain were normal on subsequent days.

\section{Serum GOT Levels}

The results of these studies are shown in Table 2. Normal serum GOT levels averaged $188 \pm 54$ units. No significant changes occurred in serum GOT levels measured 18 hours and 5-7 days after the injection of UDMH.

Tissue Sulfhydryl Levels.

The free sulfhydryl levels in liver and brain of a number of normal rats are presented in Table 3. Normal free sulfhydryl levels averaged $217 \pm 25 \mathrm{mg}$ per $100 \mathrm{~g}$ 
TABLE 2

Serum Glutamic Oxalacetic Transaminase Levels in Normal and UDMH-Treated Rats $(8 \mathrm{O} \mathrm{MG} / \mathrm{KG})$

\begin{tabular}{ccc}
\hline & \multicolumn{2}{c}{ UDMH treated } \\
\cline { 2 - 3 } $\begin{array}{c}\text { Control } \\
\text { (units/ml) }\end{array}$ & $\begin{array}{c}\text { After } 18 \text { hours } \\
\text { (units/ml) }\end{array}$ & $\begin{array}{c}\text { After } 5 / 7 \text { days } \\
\text { (units/ml) }\end{array}$ \\
\hline 165 & 205 & 220 \\
110 & 190 & 160 \\
150 & 350 & 240 \\
145 & 180 & 175 \\
290 & 230 & 188 \\
248 & 150 & 183 \\
200 & 200 & - \\
160 & 185 & - \\
222 & 250 & - \\
\hline $188 \pm 54.4^{a}$ & 182 & $191 \pm 24.2$ \\
\hline
\end{tabular}

a Average \pm standard deviation.

TABLE 3

SUlfhydryl Levels of NoRMal and UDMH-InJected Rats

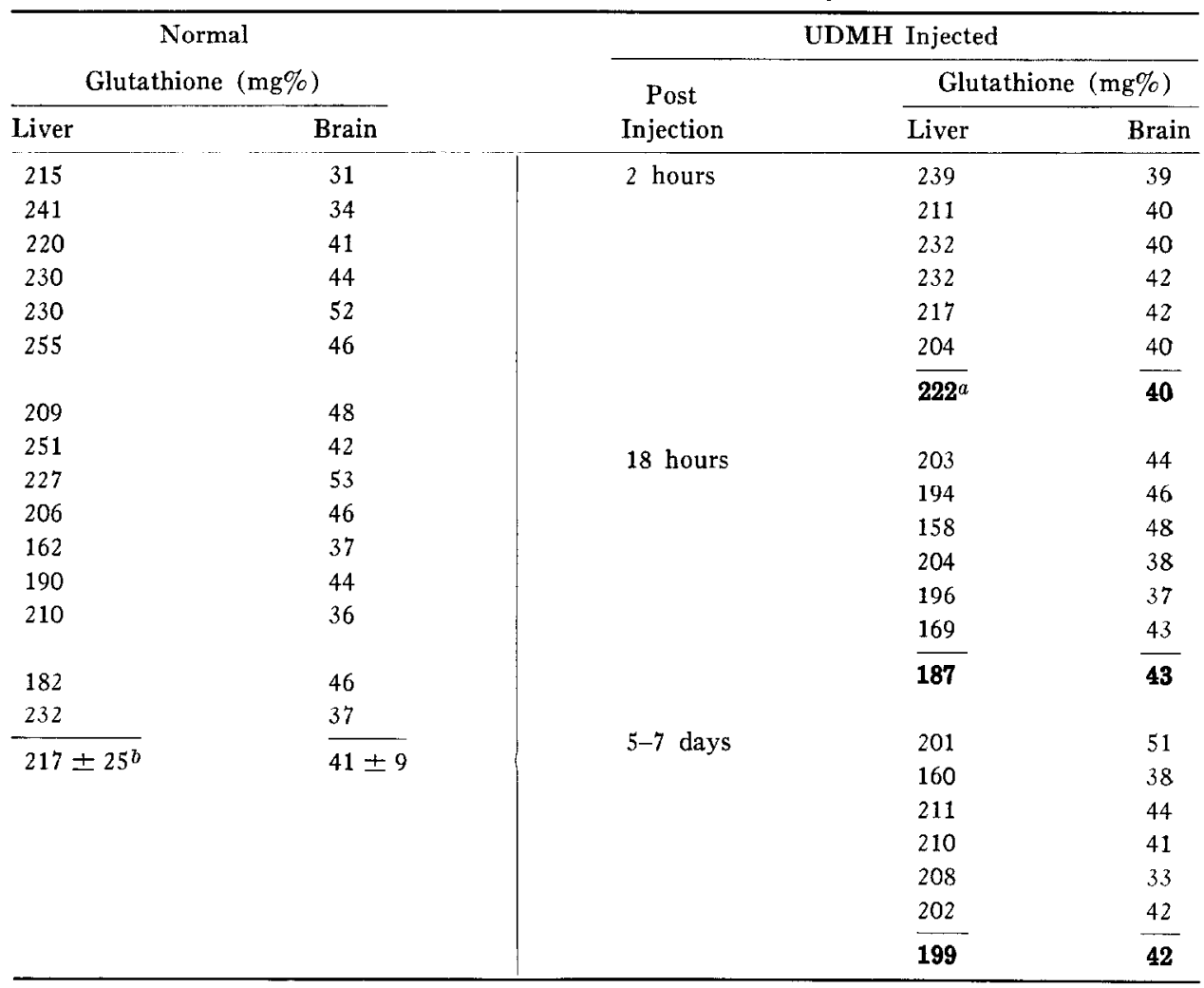

a Averages for UDMH-injected rats indicated by boldface figures.

${ }^{h}$ Average \pm standard deviation. 
of liver. These results are quite comparable with several values reported by Benesch and Benesch (1950). Normal brain sulfhydryl levels were considerably less than liver values and averaged $41 \pm 9 \mathrm{mg}$ per $100 \mathrm{~g}$ of brain. The sulfhydryl levels in rat tissues after the injection of UDMH are also shown in Table 3. Animals sacrificed at 2 hours, 18 hours, and 5-7 days after the injection averaged 222, 187, and $199 \mathrm{mg} \%$ in liver and 40,43, and $42 \mathrm{mg} \%$ respectively in brain. These values are not significantly different from control levels.

\section{Amino Acid Excretion}

The analytical data on amino acid excretion are shown in Table 4. Daily creatinine nitrogen values were quite constant within each group of animals and were not affected

TABLE 4

Creatintne $N$ and $\alpha$-Amino Acid $N$ Excretion in Rats Injected with UDMH ${ }^{a}$

\begin{tabular}{|c|c|c|c|c|c|c|c|}
\hline \multirow{2}{*}{$\begin{array}{c}\text { Doses } \\
(\mathrm{mg} / \mathrm{kg})\end{array}$} & \multirow[b]{2}{*}{ Days } & \multicolumn{2}{|c|}{ Creatinine $\mathrm{N}$} & \multicolumn{2}{|c|}{$\alpha$-Amino acid $N$} & \multicolumn{2}{|c|}{$\alpha \mathrm{AAN}:$ Creatinine $\mathrm{N}$} \\
\hline & & Control & UDMH & Control & UDMH & Control & UDMH \\
\hline \multirow[t]{6}{*}{80} & 1 & 2.6 & 2.7 & 0.360 & 0.510 & 0.136 & 0.187 \\
\hline & 2 & 2.6 & 2.4 & 0.300 & 0.240 & 0.114 & 0.100 \\
\hline & 3 & 2.9 & 2.8 & 0.274 & 0.240 & 0.094 & 0.085 \\
\hline & 4 & 3.1 & 3.1 & 0.353 & 0.200 & 0.112 & 0.065 \\
\hline & 5 & 3.0 & 3.0 & 0.300 & 0.218 & 0.100 & 0.074 \\
\hline & & & & & & \multicolumn{2}{|c|}{$\overline{0.111} \pm 0.011$} \\
\hline \multirow[t]{6}{*}{60} & 1 & 2.6 & 2.8 & 0.310 & 0.450 & 0.121 & 0.163 \\
\hline & 2 & 2.6 & 2.5 & 0.246 & 0.296 & 0.095 & 0.119 \\
\hline & 3 & 3.0 & 2.7 & 0.242 & 0.248 & 0.081 & 0.092 \\
\hline & 4 & 3.2 & 3.1 & 0.320 & 0.215 & 0.102 & 0.070 \\
\hline & 5 & 3.1 & 3.0 & 0.307 & 0.220 & 0.100 & 0.076 \\
\hline & & & & & & \multicolumn{2}{|c|}{$\overline{0.100} \pm 0.009$} \\
\hline \multirow[t]{6}{*}{40} & 1 & 2.6 & 3.1 & 0.360 & 0.490 & 0.138 & 0.158 \\
\hline & 2 & 2.6 & 2.4 & 0.284 & 0.316 & 0.107 & 0.131 \\
\hline & 3 & 3.0 & 3.0 & 0.240 & 0.306 & 0.082 & 0.104 \\
\hline & 4 & 2.7 & 3.0 & 0.344 & 0.233 & 0.129 & 0.078 \\
\hline & 5 & 3.0 & 3.1 & 0.353 & 0.274 & 0.114 & 0.088 \\
\hline & & & & & & \multicolumn{2}{|c|}{$\overline{0.114} \pm 0.016$} \\
\hline
\end{tabular}

a Each value in the table is the average obtained on four animals. Standard deviation is shown for nitrogen ratio of controls.

by UDMH injection. $\alpha$-Amino acid nitrogen excretion, however, showed a marked increase during the first 24 hours after the injection of 80,60 , or $40 \mathrm{mg}$ of UDMH per kilogram. Since creatinine nitrogen values remain relatively constant for any given animal, the $\alpha$-amino acid nitrogen to creatinine nitrogen ratio represents more clearly the change in amino acid excretion over a 24-hour period. At all levels of UDMH injection, this ratio is considerably elevated during the first 24 hours after UDMH injection. This is followed by a period of decreased amino acid excretion so that 5 days after the injection of UDMH the $\alpha$-amino acid $N$ to creatinine $N$ ratios are well below the mean for the control period. A similar group of control animals, injected only with the bicarbonate-saline solution, showed no alteration in daily amino acid excretion. 
Paper chromatographic studies of the urinary amino acids did not visually reveal any major abnormalities in amino acid distribution. There appears to be an overall increase in amino acid excretion which could readily account for the elevations found by the analytical procedures.

\section{Tissue Pathology}

Eight animals were injected with $80 \mathrm{mg}$ of UDMH per kilogram. Four animals were sacrificed 1 day, and four animals sacrificed 4 days, after the injection. The tissues appeared normal. Histopathologic studies of kidney, pancreas, cerebellum, cerebral cortex, choroid plexus, lung, liver, spleen, heart, and pancreas were essentially negative and comparable to the control group.

\section{DISCUSSION}

The approximate acute $\mathrm{LD}_{50}$ of $100 \mathrm{mg} / \mathrm{kg}$ found in this study is similar to that of $104 \mathrm{mg} / \mathrm{kg}$ reported by Back and Thomas (1963). Tremors and mild convulsions began approximately 2 hours after the injection of $80 \mathrm{mg} / \mathrm{kg}$ of UDMH. With doses of $100 \mathrm{mg} / \mathrm{kg}$, the convulsions began approximately $1 \mathrm{I} / 2$ hours after injection and rapidly progressed to severe tonic-clonic convulsions. Two of the four animals injected with $100 \mathrm{mg} / \mathrm{kg}$ died in a convulsive state approximately 4 hours after the injection. The other two rats convulsed periodically but gradually recovered and survived this dose. At a dose level of $120 \mathrm{mg} / \mathrm{kg}$, all four of the injected animals died in a convulsive state 4-6 hours after the injection.

As illustrated in Fig. 1, body weight changes in rats injected with 40, 60, or $80 \mathrm{mg}$ UDMH per kilogram were not great. Only the rats injected with $80 \mathrm{mg} / \mathrm{kg}$ showed a slight loss of weight on the first day after injection with subsequent normal weight gains.

The normal serum GOT levels found in rats injected with relatively large single doses of UDMH suggest that liver cell permeability has not been markedly altered and that sudden extensive cell death has not occurred in the liver. This is in contrast with the findings in $\mathrm{CCl}_{4}$ studies where serum GOT levels may be 50 times normal levels 24 hours after an acute exposure (Cornish and Block, 1960). Histopathologic examination of liver and other tissues 24 hours after the UDMH injection showed no tissue pathology. This finding is consistent with the serum enzyme studies. The inability to demonstrate direct tissue damage and the normal enzyme levels found in these studies would lead one to suggest that the acute toxic effects of UDMH are related primarily to its biochemical activity.

The free sulfhydryl levels in liver and brain of UDMH-treated rats were not significantly different from control levels. Animals sacrificed at 2 hours, 18 hours, and 5-7 days after UDMH injection maintained normal free sulfhydryl levels in brain and liver during this period. Thus it would appear that alterations in the availability of free sulfhydryl groups does not contribute to the pharmacologic action of UDMH.

Free amino acid excretion in urine was definitely increased 24 hours after rats were injected with UDMH at the 40,60 , or $80 \mathrm{mg} / \mathrm{kg}$ dose level. There appears to be a direct correlation of increasing amino acid excretion with increasing dose level of UDMH. UDMH when added to 24-hour control urines in amounts equal to the entire dose given to a single rat, does not interfere with this colorimetric method 
for the determination of $\alpha$-amino acids. The chromatographic studies also indicate that there is a rather general increase in overall amino acid excretion, and abnormalities related to specific amino acids are not apparent. Increased amino acid excretion, as found in these studies, could result from a number of physiological or biochemical disturbances. Tissue damage could release free amino acids into the bloodstream. However, the apparent lack of tissue damage histopathologically as well as the failure of serum GOT activity to detect liver damage suggests that the increased free amino acid excretion may be due to other factors. Massien et al. (1962) have recently shown that mice treated with L-glutamic acid- $\delta$-hydrazide tend to accumulate alanine and $\delta$-aminobutyric acid in brain, presumably due to the inhibition of enzymes involved in amino acid metabolism. Thus it is quite possible that UDMH may also interfere with amino acid metabolism not only in brain, but in other tissues as well. Interference with protein synthesis or gluconeogenesis could also result in the excretion of increased amounts of amino acids. A toxic effect on kidney resulting in partial failure to reabsorb amino acids may also be a factor. However, with the lack of evidence for structural tissue damage by histopathologic methods, it is more likely that the amino acid findings are associated with an effect of UDMH upon some more basic physiologic function or biochemical reaction.

\section{SUMMARY}

The effect of the intraperitoneal injection of UDMH on rat tissue sulfhydryl levels, serum GOT, and urinary amino acid excretion has been studied. The approximate $\mathrm{LD}_{50}$ in rats was found to be $100 \mathrm{mg} / \mathrm{kg}$.

Rats given a single injection of $80 \mathrm{mg} / \mathrm{kg}$ of UDMH show no changes in liver or brain sulfhydryl levels, nor are serum GOT levels altered by this dose.

Analyses of urine samples show that rats injected with UDMH at levels of 40,60 , or $80 \mathrm{mg} / \mathrm{kg}$ excrete correspondingly increased amounts of amino acids in the urine during the subsequent 24-hour period. It appears that this is a general increase in amino acid excretion, and abnormalities associated with specific amino acids are not apparent.

Histopathologic studies do not reveal any tissue pathology as a result of this single injection of UDMH. Since neurologic symptoms are present in these animals, the present findings tend to support the evidence for a biochemical mechanism mediating the acute toxic effects of UDMH.

\section{ACKNOWLEDGMENTS}

This work was sponsored by the Commission on Environmental Hygiene of the Armed Forces Epidemiological Board and was supported, in part, by the Medical Research and Development Command, Office of the Surgeon General, Department of the Army.

\section{REFERENCES}

Back, K. C., and Thomas, A. A. (1963). Pharmacology and toxicology of 1,1-dimethylhydrazine (UDMH). Am. Ind. Hyg. Assoc. J., 24, 23.

BENESCH, R., and BENESCH, R. (1950). Amperometric determination of soluble mercapto groups (glutathione) in blood and tissues. Arch. Biochem. 28, 43.

Comstock, C. C., Lawson, L. H., Greene, E. A., and Oberst, F. W. (1954). Inhatation toxicity of hydrazine vapor. A.M.A. Arch. Ind. Health 10, 476.

Cornish, H., and BLock, W. (1960). A study of carbon tetrachloride. II. The effect of carbon tetrachloride inhalation on serum and tissue enzymes. Arch. Environ. Health 1, 96.

Khachadurian, A., Knox, W., and Cullen, A. (1960). Colorimetric ninhydrin method for total alpha amino acids of urine. J. Lab. Clin. Med. 56, 321.

Massien, G. H., Tapia, R., and Ortega, B. G. (1962). Free amino acids in brain of mice treated with L-glutamic acid- $\gamma$-hydrazine. Biochem. Pharmacol. 11, 976. 
Medina, M., Braymer, H., and Reeves, J. L. (1962). In vitro reversal of glutamate decarboxylase inhibition induced by 1,1-dimethylhydrazine. $J$. Neurochem. 9, 307 .

ReEves, J. L. (1961). Influence of large doses of pyridoxine hydrochloride on the convulsigenic activity of UDMH in monkeys. School of Aerospace Medicine, USAF Aerospace Medical Center Bull. 62-31, Brooks Air Force Base, Texas, Dec. 1961.

Rinemart, W. E., Donati, E., and Greene, E. $\Lambda$. (1960). The sub-acute and chronic toxicity of 1,1-dimethylhydrazine vapor. Am. Ind. Hyg. Assoc. J. 21, 207.

Steinberg, D., Baldwin, D., and Ostrow, B. H. (1956). A clinical method for the assay of serum glutamic-oxaloacetic transaminase. J. Lab. Clin. Med. 48, 144. 